\title{
"IF ART HAS A KIND OF FUNCTION AT ALL, IT IS TO HELP US TO UNDERSTAND WHAT WE ARE DOING HERE": AN INTERVIEW WITH MARINA CARR ${ }^{1}$
}

\author{
Pilar Villar-Argáiz ${ }^{2}$ and Marta Alfonso Caballero ${ }^{3}$
}

Marina Carr is one of the most outstanding and prolific playwrights in Ireland's contemporary literary scene. She is the author of more than thirty plays, including The Mai (1994), Portia Coughlan (1997), On Raftery's Hill (2000), The Cordelia Dream (2008), Marble (2009), 16 Possible Glimpses (2011) and Hecuba (2015). Many of these plays have been translated into Spanish, German, French and Norwenian. Her awardwinning and critically-acclaimed plays deal incisively with issues concerning death, solitude, domesticity, love, female genealogy and Irish folklore. Her international recognition is partly explained by her unique treatment of Irish rural life, and her subtle, innovative mixture of tragedy with absurdist and comic ways.

This interview was conducted on occasion of Marina Carr's visit to the University of Granada in February 2018, as guest writer to the III International Seminar of Irish Studies. Her visit was funded through the Irish Itinerary Programme offered by EFACIS (European Federation of Associations and Centres of Irish Studies). The conversation - conducted by Pilar Villar-Argáiz and Marta Alfonso Caballero followed Carr's public reading of two of her most recognized plays: By the Bog of Cats

\footnotetext{
${ }^{1}$ Fecha de recepción: 06/12/2019.

Fecha de aceptación: 29/12/2019. Interview carried out on 15 February 2018.

${ }^{2}$ Profesora Titular de Universidad, Departamento de Filología Inglesa y Alemana, Universidad de Granada, España; $₫$ pvillar@ugr.es.

${ }^{3}$ Estudiante del Máster de Profesorado de Enseñanza Secundaria Obligatoria y Bachillerato, Formación Profesional y Enseñanza de Idiomas, Universidad de Granada, España; $₫$ martacaballero96@gmail.com.
} 
(1998) and Woman and Scarecrow (2006). In this interview, Carr talks about these two plays in relation to relevant topics, ranging from her rewriting of Greek mythology and the impact of religion in contemporary Ireland, to the relationship between feminism and literature, her portrayal of passionate women, and the influence that literary predecessors have exerted in her work.

Much has been written on your interest in revisiting Greek mythology. In By the Bog of Cats, for instance, you revise very explicitly the myth of Medea. In which way/s is Greek mythology important in your work? Could you comment on this?

Much is made of my use of Greek myth and, I must say, I write many plays that are not influenced by Greek myth at all, as they have nothing to do with it. But you are right. I am fascinated by Greek mythology and this is seen in many of my plays. I suppose that my interest comes from the fact that they are fantastic stories. The people in these myths are spectacular; the canvases are huge and I suppose it is interesting for me to look at the sides of these lives, to observe the hugeness of the emotions and passions. When I looked at Medea or took elements from this character was with the purpose of trying to understand who she was and why she would end up killing her children. I don't think I will ever figure out why or who she is. I still don't understand her; I am still not convinced of this side of love, a love that makes her kill her own children. I am not convinced that there is love there and I am not convinced with Hester either. Hester says she does it because she loves her child and she does not want to leave her child in this world without her. If you think about it, it is just spectacular ego. Nevertheless, what the writer thinks does not really matter. The play is there; it exists independently of what I think. 
I wrote By the Bog of Cats before I had children and I was desperately trying to get the final draft and finish it because I was expecting my first child. You could not be writing a play like this with a new born infant in the house, so I rushed to get it finished before the child was born. It was my first son, so I had no idea of what motherhood was or what it was going to entail. At the time, I thought, I could have a baby and I could have my life back in three weeks. You just don't know that your life is disturbed completely when a child arrives and nobody can prepare you for that. I was about to enter to motherhood myself... I don't think I was consciously aware of that at the time.

I am not an expert on Greek mythology, I don’t speak classical languages; I don't speak ancient Greek or Latin. My attraction to these myths and these plays is purely as a playwright and purely for plunder, to be honest. Greek myths are fantastic stories and I love reading about the three great Greek tragedians, out of Athens, their function within the society of the time and how they have raised... In a way, western civilization is still living out that Greek idea, with all its positive and its negative aspects. Our understanding of the world, society and the role of men and women is somehow situated. That was where it all started to define all these things.

Even though By the Bog of Cats rewrites ancient mythology, the play is at the same time hugely contemporary. Indeed, your plays are set in contemporary Ireland, as it is the case of the other play we are discussing here, Woman and Scarecrow. Why is it important for you to set your plays in contemporary settings?

I suppose because I am alive now. We have to keep making things new. Ancient stories are there to help us understand what it means to be here, to explain the world and make it a little clear for us. I think that is probably the reason. If art has a kind of function at all, it is to help us to understand what we are doing here. These stories are 
very enigmatic, and they are old, as they come out of the oral tradition, and were passed on from generation to generation long before they would have ever been written down. There is something about human nature that does not change that much. Human nature hasn't essentially changed; you see this in the newspapers all the time. In this sense, myths help us to have an artistic background for us to understand ourselves. It helps us to reflect, to engage with all these stories. It certainly helps me. I live now, so I try to make it new.

In By the Bog of Cats Hester is a Traveller, a tinker, an inner outsider marginalized on account of gender, social status and class. Are there contemporary “Hesters" in Ireland nowadays? Do we find this figure in contemporary Ireland?

I think every society probably has a version. Hester is a very particular interpretation of Medea. I do not know anything about the Travelling community now, but certainly, you open the newspaper and you see this situation: women who take themselves and their children out. There have been recently cases of men taking their children with themselves or cases where children or women die, whole families... That is not uncommon; it seems that it happens every couple of years. What seems to be a little rare is the idea of the mother killing the child and killing herself, but this horror seems to be deep in our consciousness. We have inherited this western ideal of motherhood: the sacred and virgin mother, the institutional notion of what a woman is and how she should behave. And if you think about these Greek plays, when they were written circa 2500 years BC roughly, they were trying to start a country, a civilization, and to define very tightly what the roles of men, women and children were going to be in this society. So, they had to sort all of this out and this is the reason why they invented all these things like writing about the wrong and the good, the family, the state, 
the art and the ideas. The Greeks desperately needed all these definitions, because they needed them to start a society. In a sense, plays such as Medea, The Oresteia, Phaedra, or Clytemnestra were trying to define women and their social roles and functions. All the women in these plays are outsider figures who transgress: they are powerful orators; they take power and break the law; and they do terrible things. But if you look a little deeply, you see that what they are doing is in reaction to behaviours against them.

Hester does a terrible action guided by her supposed love for her daughter. In light of this, would you consider her as a heroine or as an anti-heroine?

I am not sure ... I think Hester does what she does because she believes she is right. I think that she loves Josie but that there are other things happening there as well. There is a lot of rage towards Carthage, and there is a lot of rejection and confusion on her. One of the reasons why I wrote By the Bog of Cats is to try to understand how a woman could did that to her children, but I never found out; I never got to understand her. For me, she is not a heroine.

Is there any possibility of redemption for Hester? Did you ever think about the possibility of offering hope for this outcast figure at the end of the play?

Well, By the Bog of Cats is a tragedy so I did not think about whether there is hope for Hester or not. I truly think that she is in a battle: it is the world against her and she finally loses that battle because she ends up doing a terrible thing. However, it depends on how you look on death. If you see death as liberation, it could be taken as success. 
Where did you take the inspiration from to portray such passionate women?

All the women in my family are very passionate; they are from the West, from Connemara. They were all incredibly educated, though there was not money in the family. They ran houses, complete families and also schools. My family was full of very hot-tempered, angry women, who had a lot of passion and were full of life. They were also great story-tellers. As women from older generations, they were devoted to others and locked up to their husbands, but they were still fantastic women.

We were wondering about the resonance of the names of your characters in this play: Kilbride, Carthage and Swane... Could you expand on this?

Carthage was a very popular name where I grew up in County Offaly. I always loved the name so that is why I picked it. It has nothing to do with the influence of Greek plays, with Carthage Hannibal or the city, though people are still writing whole paragraphs about that. Mrs. Kilbride never occurred to me either and people ask if it has something to do with 'killing the bride'. That is really interesting but it never occurred to me. Writers do not need to know anything.

Something that we have really discussed in class is the influence of literary predecessors in your work. When we read By the Bog of Cats we saw traces of Samuel Beckett's Waiting for Godot in the image of Hester waiting for her mother, who never actually appears. In Woman and Scarecrow we also found intertextual references to James Joyce's "The Dead", with the imagery of the snow outside the window, and the protagonist's obsession with traveling West... To what extent has your literary background as an Irish writer influenced your writing? 
I started a MA programme on Samuel Beckett and although I never finished it, I am hugely influenced by Beckett. The first four plays I wrote were absurdist theatre and were heavily influenced by Beckett. I thought I had shaken off that influence but I had not realized the Beckett connection in By the Bog of Cats. But you are absolutely right; it would have never occurred to me in a million years. Of course, everything you read goes in, and you forget because you read so much. Writers tend to be voracious readers and forget where everything comes from. It just goes inside you and it is a question of how it is going to come out in a certain way. The idea of Woman and Scarecrow being influenced by "The Dead", I can see it absolutely, but again, it would never have occurred to me in a million years even though I love Joyce's story and I read it very single year. Of course, it is influenced by Joyce but not consciously.

How about J.M. Synge's The Tinker's Wedding? This play was in our mind when reading By the Bog of Cats. There are so many common elements in both plays: the figure of the outcast-tinker, the theme of suitable marriage, the figure of the mother-in-law who is very much concerned with money, the dark humour element...

Well, I read J.M. Synge and I love his work, and I am sure it all went in, but if you ask me now to describe The Tinker's Wedding, I can't remember. But again, unconsciously the whole stuff comes out when you are writing, so I am absolutely sure the influence is there.

Would you identify yourself as an Irish writer bearing in mind these (unconscious) literary influences? 
I suppose I am Irish. It is hard to avoid the huge number of wonderful writers that we have in the island, and yet, they are all so different. Certainly, I have no doubt that I am influenced by every one of them that I have read, and probably by the ones I haven't read because they have been influenced by each other. Writing is just one long conversation. That's all it is: one writer answering another writer. You are influenced by other writers; that's your main influence, your starting point, and then whatever the use you have of language yourself, your own particular style or voice, that's all you really got because stories are very old. All stories have been told; the only thing that can be new is the way you tell them.

My stories are Irish because I am Irish. I write and speak Hiberno-English; there is no escape in that. Nevertheless, I think that the more one focuses on the details of where one is from, strangely enough, the more it will resonate with other cultures. It goes back to the idea that we are all very similar: we tend to love and hate, we have similar difficulties and joys...The Greeks understood this and understood the complexity that all of this involves. I think that is one of the things within the whole gender war going on. Sophocles, Euripides, the Greeks... they were the first families. They gave huge voice to these transgressive women, women that took power. As a writer, there is absolute fascination with the Hecubas, Antigonies, Phaedras, Medeas in the world. There is something around about women as the bearers of children and the power that it entails. It can be upsetting maybe; perhaps it is something that needs to be controlled. The whole idea around inheritance and legitimacy, men needing to know that their child is their child, in order to control, narrow of and decide what the laws are. This is the way the world and business works. This conquering mindset and feeling is the same as it was in the Trojan war. 
Focusing now on Woman and Scarecrow, we are particularly drawn to the enigmatic character of the scarecrow in this play ... Could you talk about this figure?

I envisioned Scarecrow as the Woman's imaginary, as her silent friend, her inner voice. She is one of those voices that we all carry inside us, one of these companions we have with us in our lives; the voice inside us that may give us other ideas of what we should be doing, about what we are doing. It is the conversation we have with ourselves, in all its lights and shades.

In Spain, scarecrows are traditionally associated with masculinity and indeed, they tend to be portrayed as masculine figures. Is there an explicit intention to subvert this typical image by engendering Scarecrow as female?

I never thought about it. Where I grew up there were always scarecrows in the fields and I considered it as a very hunting image, so I chose it for the play as a figure that fits the woman's unconsciousness. However, it will be very interesting to think of it as a male figure within the play. When acting, there is no reason why it could not be played by a man. I love the idea of the man inhabiting the female and the female inhabiting the man. I wrote the play in two weeks before having my third child; it was very quickly so there was not much thought put into it. But I love that idea.

We were truly captivated by the female character (identified as Woman) in Woman and Scarecrow. As she is about to die, she realizes that she has been devoted to others her whole life but not to herself. Why is it significant that this woman dies alone? The husband goes to get the champagne, but he does not appear in time to 
be with his wife the moment she dies... Is it a way to give this woman an identity, a space of her own that she didn't have in real life?

I suppose that the good side of that is that she finally establishes a conversation with herself. I read a lot about how people die and I suppose it fascinates me. I read a book of a French psychologist and some of its stories are fantastic, about how people behave and the things they say when they are about to die. People can be so sick, there can be so much illness that they should be dead, but something is keeping them here. It is as if they were waiting to say or to do the thing they need to, so they cannot die. I heard many times that dying is like being born; that people have to be helped to die. As we are helped to get in the world, we have to be helped to get out of the world. This is very powerful and makes me think about one's own death, how we will be at the end. I just find it fascinating. Some people say it is morbid but I don't see it as morbid.

Ideally, we all want to die next to people that love us; that is an ideal situation that we all hope for, but it does not always happen like that. In a way, so much of our lives are solitary even though we are surrounded by people, or by loved ones. I think that it is important because there is something in the culture that refuses to talk about death and it is probably one of the most important things that we are going to do. I cannot imagine anything worse.

As the Woman is about to die, her Catholic aunt insists that she must confess, highlighting the big influence that the Catholic dogma and feelings of selfblame have exerted upon Ireland. In spite of such religious pressure, your female protagonist says in defiance that the only sin she has committed in life is that she has not loved herself enough, consciously interrogating Catholic teachings of submission and selflessness. To what extent is Ireland's cultural imagery still 


\section{influenced by Catholicism? Do you think that religion still exerts a lot of pressure on contemporary Irish women?}

I think it is so intrinsic in the psyche that probably we don't know that it is there. I am not sure that the ideas of blame and guilt are all bad either. I think it is good to realize that one is a sinner and therefore to improve ourselves, but I constantly feel that you are always wrong no matter what you do. That is a very Irish mind, particularly towards women: you are damned if you do something, you are damned if you don't do it. There is something very suspect about the female body, the childbirth, the role of women and their behaviour. I think that some of these systems of beliefs pray on people's insecurity about themselves. Culturally, I think that in Ireland it was very easy to target the women and keep them guilty and down. So yes, there is a huge influence on my generation, but it was not all bad. There were good things as well, as in every aspect of life: there are good and bad things. Hopefully that is changing.

\section{So, do you consider that the religious panorama is changing in Ireland right}

now?

Certainly, it is changing. And it is reflected there in Woman and Scarecrow: the confession with the aunt, the whole idea of absolution, the whole idea of God and the afterlife... These are things that I am curious about myself. I've no any particular intention when portraying the evils and goods of Catholicism; I just feel curious enough to do it. I am deeply Catholic because I went through the whole of it; I had a Catholic education and it is there. Probably it is so deep that I do not even see it. The whole idea of feeling guilty and wrong all the time is not good. I suppose the other side is to have the idea of transcendence probably necessary to make one unambitious from one's own life. 
Your depiction of passionate women is just remarkable. Is this a necessary element that you have in mind when you write a play?

Well, it depends from play to play. For example, in By the Bog of Cats I had the story of Medea. A lot of my plays tend to have, though not always, women as heroines. I give them the leading roles. I do not know why; maybe because I am a woman or because this is the way that ideas come. I have written some plays where men are equally important or even more important, so it varies from play to play. For example, when I was starting writing Portia Coughlan, all I had was the name. I wanted to write a play with a woman named Portia Coughlan and I did not know how the story was going to be when I started, and then it just emerged. It is easy to talk about a play after you read it because you know what it is about, but when you are writing it you do not know what it is going to be about, because you just make it up as you go along. Now, if it is based on an existing story, it is a little bit harder because you have to adhere to certain elements of the plot.

Your portrayal of female characters is very significant in your work, but you focus on men as well, and not exclusively on women. In spite of that, critics tend to comment exclusively on this sort of feminist agenda of your work...

I think that it is very reductive, and it has more to do with polemic politics trying to reduce the work to a feminist agenda. I absolutely refuse that and I find it quite insulting to be honest. It is as if you are not allowed the whole canvas. This is a big thing around writing and for people who write; I don't think I am alone in this. It is a given if a man writes of the whole canvas, it is his; and it is not a given if a woman writes. So, it is very easy to say "okay, you can write your way about your little women 
things, and then real writers have the whole canvas". I have to reject that because I think it is deeply insulting to women who write and I think this has to be addressed. Politics is one thing and writing is another, and I think that there is confusion around that. A writer should be free to write about anything without being reduced to certain agendas that happen to be on the rise, because they would be different within a few years. Right now, the big thing is the gender war, so we are all subjected to that. I think that is very limited; it taps into a lot of things. Women are still secondary citizens and this won't change until it is fifty-fifty; until there is equality. I'm not talking just about writing here; I'm talking right across the world. This argument is more about power than it is about gender, and I think it suits the ones in power. As long as there are gender politics, they don't have to act, they don't have to legislate, and unless it goes to law, it is pointless. It is easy to dismiss.

As you speak, we are thinking about Eavan Boland, who also refuses to be labelled as a feminist poet, on the grounds that one thing is poetry and another thing is ideology and politics. In light of this, would you agree on the label 'feminist playwright'?

No, because these are qualifications and therefore they are reductive. I am just a playwright. Why can I just be a playwright? Why cannot I have the same canvass? Obviously one is trapped in one's biology and one writes as much from one's biology. But, it is ridiculous.

Although you do not like to be called a feminist writer, do you consider that your plays can somehow exert an impact on gender issues? That they can transform conventional views on gender roles? 
I am myself a raging feminist; of course I am. It is impossible if you are a woman nowadays not to be raging. I am a feminist but when I write, I am not a feminist. When I write, I want to tell a story. People say that my women characters are strong and I think they are, the same as my models as very strong women: my mother, my grandmother, all my aunts. They were powerful, angry and very strong and none of them would have called themselves feminists. They got married, they had children and they were all very happy. And to me, that is not feminism. Anyway, if that is the definition of feminism, then it is feminism. It is very easy to reduce a woman writer to feminism because it is very safe, but at the end, it is as if you have literature and then women's literature. This is the real stuff nowadays. That is how it is perceived. And, whether we like it or not the most powerful structures in the world are run by men generally white, quite old - and the rest of us are just trying to survive. A good friend of mine says that we all have to eat food coming from patriarch because it is the ruling structure nowadays, and pretending that it is not that way is useless at all. So I am not saying that I am not a feminist, but that it is an easy label to reduce certain works of literature of being part of the whole literary canvass. We do not think how humiliating is not to be considered equal just because you are a woman. The world is a mess, a big mess. A good thing that we must remember is that there are good people as well. But unfortunately, they are not in power.

In the two plays we have read in class (By the Bog of Cats and Woman and Scarecrow), it seems that male characters make women unhappy. What is it that your male characters lack in order to be good companions for the female characters? 
I think that, in general, women need to be loved, although not always of course. In the case of Hester in By the Bog of Cats, she has been betrayed by a man who does love her, but he is greedy. He wants land and money, and is prepared to sacrifice her and the child for that. In Woman and Scarecrow, the husband has betrayed her and yet he claims to love her. We are all different; it is not that women are easy. Maybe we have insisted on men overcompensating for our disappointments, and then you realize that most men are trying to get by as well. There are only few men who have the power; the rest are just like women, trying to survive and live. They want things that women also want, like love and family, and a decent lifestyle. All this can be a struggle for men. It is not easy for young men in the world now; in a way they still have to proof themselves in a way that women don't have to. There is still the idea that if a woman wakes up in the morning and decides that she wants to get married and have ten children, that is fine, but if a man does it, he must think about feeding those children, building a house for them, buying clothes and all the stuff they need for living. Within that kind of philosophy, it is still very acceptable for a woman to be a domestic goddess. 